\title{
PEMIDANAAN TERHADAP PERBUATAN MENGHILANGKAN MAYAT YANG DILAKUKAN ANAK (STUDI TERHADAP PUTUSAN MAHKAMAH AGUNG NO. 774K / PID.SUS / 2015)
}

\section{Heppi Florensia}

(Mahasiswa Program S1 Fakultas Hukum Universitas Tarumanagara)

(E-mail: heppi.florensia@gmail.com)

\section{Dr. Mety Rahmawati S.H., M.H.}

(Corresponding Author)

(Dosen Hukum Pidana, Fakultas Hukum Universitas Tarumanagara. Meraih Sarjana Hukum (S.H.) pada Fakultas Hukum Universitas Trisakti (1989), Magister Hukum (M.H.) pada Fakultas Hukum

Universitas Tarumanagara (1996), Doktor (Dr.) pada Fakultas Hukum Universitas Trisakti (2013)

\begin{abstract}
Criminalization of the offender especially in the perpetrators of children under age is as a sanction that tells implied to someone who performs acts meet certain conditions. Often in prosecuting a criminal case the Public Prosecutor is wrong in deciding what articles should be imposed on the perpetrator. As one case of Supreme Court verdict No.774K/PID.SUS/2015 with 16-year-old defendant Dicky Pranata prosecuted by the Prosecutor with Article 340 of the Penal Code juncto Article 56 of the Criminal Code is a criminal act of premeditated murder, in which the elements of Article 340 of the Criminal Code are not fulfilled the defendant's self but the existence of other crimes Article 181 of the Criminal Code of disappearance committed by the defendant. The defendant was sentenced to 10 years in prison at the District Court, while the defendant was released from the sentence of the Court of Appeal and Cassation. The problem in this research is whether the act of the perpetrator fulfills the elements in Article 340 juncto Article 56 paragraph (1) of the Criminal Code juncto Article 1 paragraph (3) SPPA Act and Article 181 of the Criminal Code? How to base criminal offenses in the Supreme Court ruling case No.774K/PID.SUS/2015? The researcher examines the problem with normative juridical method. Based on the analysis result that the defendant is not proven to commit element of crime Article $340 \mathrm{KUHP}$, but the existence of criminal act Article 181 of Criminal Code which has been done by defendant.
\end{abstract}

Keywords : punishment, removal of corpses, child 


\section{PENDAHULUAN}

\section{A. Latar Belakang}

Negara Republik Indonesia adalah negara hukum, seperti yang tertuang di dalam Undang-Undang Dasar Republik Indonesia 1945 (UUD 1945) dalam Pasal 1 ayat (3). Dalam penjelasan dari UUD 1945 tersebut dengan tegas disebutkan bahwa Indonesia adalah negara hukum (rechstaat) bukan negara kekuasaan (machstaat). ${ }^{1}$ Jelaslah bahwa cita-cita negara hukum (rule of law) yang terkandung dalam UUD 1945 bukanlah sekedar negara yang berlandaskan dari sembarang hukum.

Agar hukum yang ada pada suatu negara tidak menjadi sewenang-wenang dan diharapkan dapat menciptakan suatu keadilan perlu dilakukannya suatu penegakan hukum. Penegakan hukum khususnya penegakan pada hukum pidana dalam negara modern telah digambarkan dengan ciri-ciri birokratis, yang terlihat terpisah dari fungsi polisi sebagai penyidik, jaksa sebagai penuntut umum, hakim sebagai pihak yang mengadili, dan lembaga pemasyarakatan yang membina pelaku agar dapat kembali menjadi masyarakat seutuhnya. Melalui penegakan inilah hukum menjadi kenyataan.

Produk yang dihasilkan dalam proses peradilan khususnya peradilan pidana tersebut adalah putusan hakim. Dalam suatu putusan, idealnya harus memenuhi unsur-unsur idee des recht (cita hukum) secara proporsional, yaitu kepastian hukum (rechssicherheit), kemanfaatan (zweckmassigheir) dan keadilan (gerechtigheit). ${ }^{2}$ Putusan bebas khususnya dalam kasus tindak pidana pembantuan pembunuhan berencana dengan mutilasi disertai dengan menghilangkan mayat korban bermaksud untuk menjualnya, menjadi hal yang kontroversial dalam masyarakat, karena perbuatan seorang pelaku dalam tindak pidana adalah suatu perbuatan yang keji dengan tega melakukan

\footnotetext{
${ }^{1}$ Munir Fuady, Teori Negara Hukum Modern (Rechstaat), (Bandung: PT Refika Aditama, 2009), hal. 179

${ }^{2}$ Bambang Sutiyoso, Metode Penemuan Hukum, Cetakan ke-4, (Yogyakarta: UII Press, 2012), hal. 188
} 
membunuh orang ditambah dengan menghilangkan mayat korban karena alasan-alasan tertentu. Terlebih jika pelaku yang melakukan tersebut adalah anak yang menjadi masalah serius dihadapi oleh setiap negara.

Penyelesaian tindak pidana pada anak perlu ada perbedaan antara pelaku orang dewasa dengan pelaku anak, dilihat dari kedudukannya seorang anak secara hukum belum dibebani kewajiban dibandingkan orang dewasa, selama seseorang masih disebut anak, selama itu pula dirinya tidak dituntut pertanggungjawaban, bila timbul masalah terhadap anak diusahakan bagaimana haknya dilindungi hukum. ${ }^{3}$ Seperti yang tertulis dalam Pasal 1 ayat (1) Undang-Undang Nomor 17 Tahun 2016 tentang Perubahan Kedua Atas Undang-Undang Nomor 23 Tahun 2002 Tentang Perlindungan Anak (UU PA) bahwa definisi anak adalah seseorang yang belum berusia 18 (delapan belas) tahun, termasuk anak yang masih dalam kandungan. ${ }^{4}$ Kemudian Pasal 1 ayat (3) Undang-Undang Nomor 11 Tahun 2012 tentang Sistem Peradilan Pidana Anak (UU SPPA) bahwa anak yang berkonflik dengan hukum selanjutnya disebut anak adalah anak yang telah berumur 12 (dua belas) tahun, tetapi belum berumur 18 (delapan belas) tahun yang melakukan tindak pidana. ${ }^{5}$ Lalu Pasal 21 ayat (1) UU SPPA dijelaskan bahwa batas umur 12 (dua belas) tahun bagi anak dapat diajukan ke sidang anak didasarkan pada pertimbangan sosiologis dan psikologis, dan pedagogis bahwa anak yang belum mencapai umur 12 (dua belas) tahun dianggap belum dapat mempertanggungjawabkan perbuatannya. ${ }^{6}$ Maka bagi anak yang melakukan tindak pidana, yang telah berusia 12 (dua belas) tahun atau lebih dapat bertanggungjawab atas perbuatannya.

\footnotetext{
${ }^{3}$ Bunadi Hidayat, Pemidanaan Anak di Bawah Umum (Bandung: PT Alumni, 2010), hal. 2

${ }^{4}$ Undang-Undang Nomor 17 Tahun 2016 tentang Perubahan Kedua Atas Undang-Undang Perlindungan Anak (UU PA), Pasal 1 ayat (1)

${ }^{5}$ Undang-Undang Nomor 11 Tahun 2012 tentang Sistem Peradilan Pidana Anak (UU SPPA), Pasal 1 ayat (3)

${ }^{6}$ Ibid., Pasal 21 ayat (1)
} 
Seringkali dalam melakukan perbuatan tindak pidana, ikut disertakan orang lain dalam tindakannya. Dalam hal turut serta diatur dalam KUHP dengan “delik penyertaan”, diatur pada Bab V Buku I KUHP berarti turut sertanya seorang atau lebih pada waktu seorang lain melakukan suatu tindak pidana. Rumusan ini terlihat pada Pasal 55 dan Pasal 56 KUHP. Oleh kedua pasal ini diadakan lima golongan peserta tindak pidana yaitu yang melakukan perbuatan (plegen dader), yang menyuruh melakukan perbuatan (doen plegen, middelijke dader), yang turut melakukan perbuatan (medeplegen, mededader), yang membujuk supaya perbuatan dilakukan (uitlokken, uitlokker), yang membantu perbuatan (medeplichtig zijn, medeplichtige). ${ }^{7}$ Penyertaan orang yang disertakan pun dalam tindak pidana dapat dilakukan oleh seorang anak, karena dengan alasan jika anak tidak dapat mempertanggungjawabkan perbuatannya dan juga anak mudah untuk disuruh melakukan suatu perbuatan.

Kemudian dalam menjatuhkan hukuman pada seseorang yang melakukan tindak pidana, hakim hanya memeriksa berdasarkan dari surat dakwaan yang diajukan Penuntut Umum padanya. Surat dakwaan merupakan hal paling penting dalam proses pidana, karena dalam surat dakwaanlah memuat akan fakta-fakta yang didakwakan terhadap seorang terdakwa, dan hakim hanya boleh memutus atas dasar fakta-fakta tersebut tidak boleh kurang atau pun lebih. Lalu bagaimana jika dalam suatu kasus pidana dimana pelaku melakukan suatu tindak pidana tetapi yang dituntut oleh Penuntut Umum dalam surat dakwaannya bukan merupakan tindak pidana yang dilakukan oleh pelaku, melainkan yang dituntut dalam surat dakwaannya adalah tindak pidana lain yang tidak dilakukan pelaku.

Seperti salah satu contoh kasus pada putusan Mahkamah Agung No. 774 K / PID.SUS / 2015 dalam duduk perkara dimana Terdakwa (anak 16 (enam belas) tahun) bersama dengan Saksi I dan Saksi II telah melakukan suatu

\footnotetext{
${ }^{7}$ Wirjono Prodjodikoro, Asas-Asas Hukum Pidana di Indonesia, (Bandung: PT Refika Aditama, 2014), hal. 118
} 
tindak pidana. Sebelumnya tindak pidana sudah dilakukan oleh Saksi I dan Saksi II pada seorang Korban dengan melakukan pembunuhan disertai mutilasi yang mana pembunuhan tersebut sebelumnya sudah direncanakan oleh kedua saksi dengan maksud untuk memperoleh kesaktian. Terdakwa yang diajak oleh kedua saksi ke tempat kejadian pembunuhan terjadi menemukan Korban sudah dalam keadaan tidak bernyawa dengan leher berlubang mengeluarkan darah, saat melihat itu Terdakwa mengatakan "Tega kalian" lalu Saksi I membalas "Kau mau seperti ini". Kemudian dengan permintaan Saksi II, Terdakwa membuka kantong plastik untuk memasukkan potongan-potongan daging Korban. Selesai memasukkan daging Korban dalam 7 (tujuh) kantong plastik, mereka menutup bagian tubuh korban yang tersisa dengan daun kering. Kemudian ketiganya meninggalkan lokasi kejadian dengan berbonceng tiga menggunakan sepeda motor sambil membawa 7 (tujuh) plastik berisi daging, jantung, dan alat kelamin Korban yang bermaksud untuk menjual daging tersebut ke warung makan. Tetapi di tengah perjalanan, Terdakwa meminta turun dan Saksi I yang mengendarai motor menurunkan Terdakwa, kemudian Terdakwa kembali pulang ke rumahnya. Setelah peristiwa tersebut, terdakwa tidak pernah bertemu lagi secara intens dengan Saksi I maupun Saksi II, dan Terdakwa pun tidak pernah melaporkan kejadian tersebut kepada pihak berwajib atau orang tua terdakwa sendiri.

Mengenai kasus tersebut Penuntut Umum dalam tuntutannya menuntut dengan dakwaan pertama Pasal 340 juncto Pasal 55 ayat (1) ke-1 KUHP juncto Pasal 1 ke-3 UU SPPA dan dakwaan kedua Pasal 340 juncto Pasal 56 ayat (1) ke-1 KUHP juncto Pasal 1 ke-3 UU SPPA. Pada putusan di tingkat Pengadilan Negeri memutuskan pidana penjara pada Terdakwa 10 (sepuluh) tahun dikurangi selama Terdakwa menjalani masa penahanan dengan melihat pada dakwaan kedua, mengingat bahwa Terdakwa masihlah seorang anak 16 (enam belas) tahun, yang mana dalam Pasal 81 ayat (2) UU SPPA dijelaskan 
bahwa pidana penjara yang dapat dijatuhkan kepada Anak paling lama 1/2 (satu per dua) dari maksimum ancaman pidana penjara bagi orang dewasa ${ }^{8}$, dimana penjatuhan pidana penjara bagi orang dewasa yang telah melakukan tindak pidana Pasal 340 KUHP adalah pidana mati atau pidana penjara seumur hidup, atau paling lama dua puluh tahun. Kemudian mengajukan ke tingkat Banding, dengan putusan Pengadilan Tinggi yang membatalkan putusan Pengadilan Negeri sebelumnya dan menyatakan bahwa Terdakwa tidak terbukti secara sah dan menyakinkan melakukan tindak pidana pada dakwaan kedua Pasal 340 juncto Pasal 56 ayat (1) ke-1 KUHP juncto Pasal 1 ke-3 UU SPPA. Mengajukan pada tingkat Kasasi yang menolak permohonan kasasi.

Padahal jika melihat pada kasus kejadian adanya pasal yang dilanggar selain dari Pasal 340 KUHP mengenai pembunuhan berencana, yaitu Pasal 181 KUHP mengenai membawa lari atau menghilangkan mayat dengan maksud menyembunyikan kematian. Memang dalam Putusan Pengadilan Tinggi menyatakan bahwa Terdakwa tidak terbukti secara sah dan menyakinkan melakukan tindak pidana Pasal 340 juncto Pasal 56 ayat (1) ke1 KUHP juncto Pasal 1 ke-3 UU SPPA, karena tindak pidana pembunuhan sudah terjadi sebelum Terdakwa datang di lokasi kejadian. Tetapi dalam hal membawa lari atau menghilangkan mayat korban merupakan suatu tindak pidana yang diatur dalam Pasal 181 KUHP dilakukan oleh Terdakwa bersama dengan kedua saksi yang melakukan pembunuhan. Dalam putusan Pengadilan Negeri maupun Pengadilan Tinggi tidak dipertimbangkan mengenai perbuatan pelaku yang turut serta dalam membantu memindahkan bagian tubuh korban (daging korban dalam plastik) ke tempat lain, yang seharusnya tindakan tersebut dapat dipertimbangkan sebagai suatu tindak pidana yang dilakukan oleh Terdakwa. Hal ini dapat terjadi di dalam dakwaan yang dibuat oleh Penuntut Umum yang tidak dimasukkan tuntutan mengenai tindak pidana

\footnotetext{
${ }^{8}$ UU SPPA, Op. Cit., Pasal 81 ayat (2)
} 
Pasal 181 KUHP. Melihat pada surat dakwaan kasus dimana Penuntut Umum memberikan dengan dakwaan subsidair, yang mana seharusnya Penuntut Umum dapat memasukkan surat dakwaan kumulatif yaitu mengenai Pasal 340 juncto Pasal 56 KUHP dan Pasal 181 juncto Pasal 56 KUHP mengingat adanya penyertaan yang dilakukan oleh Terdakwa dalam tindak pidana tersebut. Sedangkan hakim hanya melihat dari tuntutan yang diberikan oleh Jaksa dalam surat tuntutannya. Mengingat adanya asas ultra petitum partium yang melarang hakim untuk memutus melebihi apa yang dituntut. ${ }^{9}$

Atas dasar uraian di atas, maka dalam penelitian ini penulis tertarik untuk meneliti dengan judul "Pemidanaan Terhadap Perbuatan Menghilangkan Mayat yang dilakukan Anak (Studi Terhadap Putusan Mahkamah Agung No. 774 K / PID.SUS / 2015)."

\section{B. Permasalahan}

Berdasarkan latar belakang yang telah dikemukakan, maka yang menjadi rumusan permasalahan sebagai berikut :

1. Apakah perbuatan pelaku memenuhi unsur-unsur dalam Pasal 340 juncto Pasal 56 ayat (1) ke-1 KUHP juncto Pasal 1 ke-3 UU SPPA dan Pasal 181 juncto Pasal 56 ayat (1) ke-1 KUHP juncto Pasal 1 ke-3 UU SPPA?

2. Bagaimana dasar peringan pidana dalam kasus putusan Mahkamah Agung No. 774K / PID.SUS / 2015?

\section{Metode Penelitian}

Penelitian ini hendak ingin menganalisis mengenai unsur tindak pidana yang dilakukan oleh seorang terdakwa pelaku pembantuan pembunuhan berencana yang dilakukan oleh seorang anak dibawah umur pada putusan No. 774K / PID.SUS / 2015 dengan mengggunakan metode penelitian hukum normatif, diatur mengenai tindak pidana dalam hal kejahatan terhadap nyawa dan kejahatan terhadap ketertiban umum seperti dalam KUHP. Penelitian ini

\footnotetext{
${ }^{9}$ M. Natsir Asnawi, Hermeneutika Putusan Hakim, (Yogyakarta: UII Press Yogyakarta, 2014), hal. 46
} 
akan menggunakan pendekatan undang-undang yang ketentuan-ketentuan mengenai tindak pidana diatur dalam KUHP dan mengenai pemidanaan terhadap anak yang diatur dalam UU SPPA. Selanjutnya putusan akan dianalisis sesuai dengan undang-undang yang akan digunakan untuk mendapatkan hasil mengenai tindak pidana mana yang telah dilakukan oleh anak dalam kasus selain dengan tindak pidana yang telah dituntut oleh Jaksa Penuntut.

\section{PEMBAHASAN}

Dalam hukum pidana adanya suatu tindak pidana (strafbaar feit) apabila perbuatan itu telah cocok dengan apa yang ada atau dirumuskan dalam undangundang. Pembentuk undang-undang dalam merumuskan tindak pidana selalu menyebutkan "melawan hukum" dalam pasal-pasalnya. Namun demikian unsur melawan hukum harus selalu ada dalam setiap rumusan delik. Hal ini dapat dilihat dalam memori penjelasan yang menyebutkan bahwa pada beberapa rumusan delik dengan nyata-nyata disebut perkataan bersifat melawan hukum karena tanpa ditambah perkataan itu, maka ada bahaya yaitu bahwa mereka yang menggunakan haknya akan termasuk dalam ketentuan undang-undang pidana. ${ }^{10}$ Adapun tindak pidana dengan pengertiannya secara umum dibedakan menjadi dua, yaitu menurut pandangan teori monistis dan pandangan teori dualistis.

\section{Pandangan Teori Monistis}

Teori monistis tidak memisahkan antara tindak pidana dengan kesalahan. Karena kesalahan merupakan unsur tindak pidana, maka berdasarkan asas 'tiada pidana tanpa kesalahan', kesalahan juga merupakan unsur pertanggungjawaban pidana. Terbuktinya seluruh unsur tindak pidana dapat membuktikan tindak pidana sekaligus adanya pertanggungjawaban pidana.

\footnotetext{
${ }^{10}$ Roeslan Saleh, Sifat Melawan Hukum dari Perbuaan Pidana, (Jakarta: Aksara Baru, 1983), hal. 56
} 
Terbuktinya tindak pidana yang di dalamnya terdapat unsur kesalahan, pembuat bertanggung jawab atas tindak pidana itu. ${ }^{11}$

2. Pandangan Teori Dualistis

Teori dualistis memisahkan secara tegas antara tindak pidana dengan kesalahan. Kesalahan bukan unsur tindak pidana, tetapi kesalaan merupakan unsur untuk menentukan pertanggungjawaban pidana. Kesalahan (mens rea) harus dipisahkan dengan tindak pidana (actus reus). Pertanggungjawaban pidana hanya berkaitan dengan mens rea, karena pertanggungjawaban pidana hanya didasarkan pada kesalahan (mens rea). Mens rea selalu berkaitan dengan keadaan mental atau psychis pembuat, sementara actus reus selalu berkaitan dengan perbuatan yang bersifat melawan hukum. ${ }^{12}$

Suatu perbuatan dapat dikatakan sebagai tindak pidana apabila perbuatan tersebut telah memenuhi beberapa unsur. Sesuatu tindakan itu dapat merupakan eend doen dan een niet doen atau dapat merupakan "hal melakukan sesuatu" ataupun "hal tidak melakukan sesuatu", yang terakhir ini dalam doktrin juga sering disebut sebagai een nalaten yang juga berarti "hal mengalpakan sesuatu yang diwajibkan (oleh undang-undang)". ${ }^{13}$ Menurut Moeljatno untuk terjadinya suatu tindak pidana harus dipenuhinya unsur-unsur sebagai berikut:

1. Adanya perbuatan (manusia);

2. Memenuhi rumusan dalam undang-undang;

3. Bersifat melawan hukum. ${ }^{14}$

Kemudian sebagai hasil dari sudah dilakukannya suatu tindak pidana adalah dengan penerimaan sanksi berupa pemberian hukuman pada pelaku tindak pidana tersebut. Dalam hukum pidana Pasal 10 KUHP membagi hukuman dalam dua

11 Agus Rusianto, Tindak Pidana dan Pertanggungjawaban Pidana; Tinjauan Kritis Melalui Konsistensi antara Asas, Teori, dan Penerapannya, (Jakarta: Kencana, 2016), hal. 15

12 Ibid.

${ }^{13}$ P.A.F. Lamintang dan Franciscus Theojunior Lamintang, Dasar-Dasar Hukum Pidana di Indonesia, Cetakan ke-2, (Jakarta: Sinar Grafika, 2016), hal. 191

${ }^{14}$ Mulyati Pawennei dan Rahmanuddin Tomalili, Hukum Pidana, (Jakarta: Mitra Wacana Media, 2015), hal. 15 
jenis, yaitu pidana pokok dan pidana tambahan. Pidana pokok yang terdiri dari pidana mati, pidana penjara, pidana kurungan, pidana denda, dan pidana tutupan. Sedangkan Pidana tambahan terdiri dari pencabutan hak-hak tertentu, perampasan barang-barang tertentu, dan pengumuman putusan hakim.

Tujuan pidana dan tujuan hukum pidana adalah dua hal yang berbeda. Kendatipun demikian, tujuan pidana tidak terlepas dari aliran dalam hukum pidana. Jika aliran-aliran dalam hukum pidana yang mendasari tujuan hukum pidana terdiri dari aliran klasik, aliran modern, dan aliran neo-klasik, maka tujuan pidana secara garis besar juga terbagi menjadi tiga, yakni teori absolut, teori relatif, dan teori gabungan. Akan tetapi dalam perkembangannya selain ketiga teori tersebut ada juga teori-teori kontemporer tentang tujuan pidana.

1. Teori absolut atau teori pembalasan (retributive / vergeldings theorieen)

Menurut teori ini pidana dijatuhkan semata-mata karena orang telah melakukan suatu kejahatan atau tindak pidana (quia peccatum est). Pidana merupakan akibat mutlak yang harus ada sebagai suatu pembalasan kepada orang yang melakukan kejahatan. Jadi dasar pembenaran dari pidana terletak pada adanya atau terjadinya kejahatan itu sendiri.. ${ }^{15}$

2. Teori relatif atau teori tujuan (utilitarian/doeltheorieen)

Menurut teori ini memidana bukanlah untuk memuaskan tuntutan absolut dari keadilan. Pembalasan itu sendiri tidak mempunyai nilai, tetapi hanya sebagai sarana untuk melindungi kepentingan masyarakat. Oleh karena itu menurut Johannes Andenaes, teori ini dapat disebut sebagai "teori perlindungan masyarakat" (the theory of social defence). ${ }^{16}$ Jadi dasar pembenaran adanya pidana menurut teori ini adalah terletak pada tujuannya.

3. Teori Gabungan atau teori integratif (verenigings theorieen)

\footnotetext{
${ }^{15}$ Muladi \& Barda Nawawi, Teori-Teori dan Kebijakan Hukum Pidana, (Bandung: Alumni, 1992), hal. 10-11

${ }^{16}$ Ibid., hal. 16
} 
Menurut teori gabungan bahwa tujuan pidana itu selain membalas kesalahan penjahat, juga dimaksudkan untuk melindungi masyarakat dengan mewujudkan ketertiban. Teori ini menggunakan menggunakan kedua teori, yaitu, teori absolut dan teori relatif sebagai dasar pemidanaan. Teori integratif dapat dibagi menjadi tiga golongan, yaitu:

a. Teori integratif yang menitikberatkan pembalasan, tetapi tidak boleh melampaui batas apa yang perlu dan sudah cukup untuk dapat mempertahankan tata tertib masyarakat.

b. Teori integratif yang menitikberatkan pada pertahanan tata tertib masyarakat, tetapi tidak boleh lebih berat dari suatu penderitaan yang beratnya sesuai dengan beratnya perbuatan yang dilakukan oleh narapidana.

c. Teori integratif yang menganggap harus ada keseimbangan antara kedua hal tersebut. ${ }^{17}$

\section{Teori kontemporer}

Selain teori absolut, teori relatif, dan teori gabungan sebagai tujuan pidana, dalam perkembangannya terdapat teori-teori baru yaitu teori kontemporer yang berasal dari ketiga teori tersebut, dengan penjelasan sebagai begitu:

a. Teori Efek Jera

Wayne R. Lafave menyebutkan salah satu tujuan pidana adalah sebagai deterrence effect atau efek jera agar pelaku kejahatan tidak lagi mengulangi perbuatannya. Tujuan pidana sebagai deterrence effect pada hakikatnya sama dengan teori relatif terkait dengan prevensi khusus. Jika prevensi umum bertujuan agar orang lain tidak melakukan kejahatan, maka prevensi khusus ditujukan kepada pelaku yang telah dijatuhi hukuman agar tidak mengulangi lagi kejahatannya. ${ }^{18}$

${ }^{17} \mathrm{Ibid}$.

${ }^{18}$ Eddy O.S. Hiraej, Prinsip-Prinsip Hukum Pidana, Edisi Revisi, (Yogyakarta: Cahaya Atma Pustaka, 2015), hal. 42 


\section{b. Teori Edukasi}

Pada dasarnya teori edukasi menyatakan bahwa pidana bertujuan sebagai edukasi kepada masyarakat mengenai mana perbuatan yang baik dan mana perbuatan yang buruk. Seorang pelaku kejahatan harus mendapatkan hukuman yang setimpal atas perbuatan yang dilakukannya untuk memberi pelajaran kepada orang lain agar tidak melakukan perbuatan yang sama. ${ }^{19}$

c. Teori Rehabilitasi

Tujuan pidana yang lain adalah rehabilitasi, yang artinya, pelaku kejahatan harus diperbaiki ke arah yang lebih baik, agar ketika kembali ke masyarakat ia dapat diterima oleh komunitasnya dan tidak lagi mengulangi perbuatan jahat. Menurut Thomas Aquinas, tatkala negara menjatuhkan pidana dengan daya kerja pengobatan, maka perlu diberikan perhatian terhadap prevensi umum dan prevensi khusus. Artinya pidana sebagai obat adalah dalam rangka memperbaiki terpidana agar kembali ke masyarakat tidak lagi mengulangi perbuatannya sebagaimana tujuan prevensi khusus. $^{20}$

d. Teori Pengendalian Sosial

Salah satu tujuan dari pidana adalah sebagai pengendalian sosial menurut Wayne R. Lafeve, yang berarti pelaku kejahatan diisolasi agar tindakan berbahaya yang dilakuak tidak merugikan masyarakat. Secara tegas dimaksud bahwa masyarakat harus dilindungi dari tindakan jahat pelaku. $^{21}$

e. Teori Keadilan Restoratif

Tujuan pidana juga untuk memulihkan keadilan atau dikenal dengan istilah restorative justice atau keadilan restoratif. Restorative justice

${ }^{19}$ Ibid., hal. 43

${ }^{20} \mathrm{Ibid}$.

${ }^{21}$ Ibid., hal. 44 
dipahami sebagai bentuk pendekatan penyelesaian perkara menurut hukum pidana dengan melibatkan pelaku kejahatan, korban, keluarga korban atau pelaku dan pihak lain yang terkait untuk mencari penyelesaian yang adil dengan menekankan pada pemulihan kembali pada keadaan semula dan bukan pembalasan. $^{22}$

Mengenai kasus putusan Mahkamah Agung No. 774K / PID.SUS / 2015 dengan terdakwa Dicky Pranata yang didakwaan Pasal 340 juncto Pasal 56 ayat (1) ke-1 KUHP juncto Pasal 1 ke-3 UU SPPA, dapat dilihat jika dalam tindak pidana pembunuhan berencana yang diatur pada Bab XIX Buku II KUHP tentang kejahatan terhadap nyawa dalam Pasal 340 KUHP. ${ }^{23}$ Kejahatan ini dapat dikatakan adalah suatu pembunuhan biasa (doodslag) (Pasal 338 KUHP), akan tetapi ditambah dengan dilakukannya unsur "dengan rencana terlebih dahulu." 24 Perencanaan yang dilakukan dapat berupa tempat (tempus delicti), waktu (locus delicti), atau pun senjata (instrument) yang digunakan untuk menghabisi nyawa korban. ${ }^{25}$

Dalam putusan tersebut dinyatakan bahwa terdakwa tidak terbukti secara sah dan meyakinkan telah melakukan tindak pidana pembunuhan berencana secara bersama-sama yang putusan ini menguatkan Putusan Pengadilan Tinggi sebelumnya, seperti yang sudah didakwakan oleh Penuntut Umum dalam tuntutannya. Berbeda dengan putusan yang telah diputus oleh Pengadilan Negeri yang memutuskan pada tingkat pengadilan pertama bahwa Terdakwa terbukti secara sah dan menyakinkan telah melakukan pembunuhan berencana secara bersama-sama sesuai dengan tuntutan dari dakwaan kedua yang di dakwakan oleh Penuntut Umum dan menjatuhkan terdakwa dengan hukuman pidana penjara selama 10 (sepuluh) tahun.

${ }^{22}$ Ibid.

${ }^{23}$ KUHP, Op. Cit., Pasal 340

${ }^{24}$ R. Soesilo, Kitab Undang-Undang Hukum Pidana (KUHP) Serta Komentar-Komentarnya Lengkap Pasal Demi Pasal, (Bogor: Politeia, 1976), hal. 208

${ }^{25}$ Firman Wijaya, wawancara dengan penulis, Dosen PLKH I Fakultas Hukum Universitas Tarumanagara, Jakarta, 8 Mei 2018 
Berdasarkan fakta-fakta yang terungkap dipersidangan pada kasus putusan Mahkamah Agung No. 774K / PID.SUS / 2015, maka dinyatakan bahwa pembuktian mengenai unsur-unsur tindak pidana yang didakwakan oleh karena surat dakwaan yang disusun secara subsidair oleh Penuntut umum maka akan membuktikan unsur-unsur melanggar Pasal 340 KUHP juncto Pasal 56 ayat (1) ke-1 KUHP juncto Pasal 1 ke-3 UU SPPA dan Pasal 181 sebagai berikut:

\section{Pasal 340 KUHP}

a. Unsur "Barangsiapa"

Dimaksud barang siapa adalah setiap orang atau siapa saja selaku subyek hukum, pendukung hak serta kewajiban, serta dapat dikenakan pertanggungjawaban pidana. ${ }^{26}$ Berdasarkan fakta hukum, bahwa Terdakwa Dicky Pranata adalah seorang anak berusia 16 (enam belas) tahun, sudah dianggap dewasa jika sudah berusia 16 (enam belas) tahun dan belum lebih dari 21 tahun dapat mempertanggungjawabkan perbuatannya melihat pada Pasal 45 KUHP. Sebagaimana tercantum mengenai identitas Terdakwa di dalam dakwaan dan putusan pengadilan sehingga dalam hal ini tidak terjadi error in persona.

b. Unsur "dengan sengaja"

Dalam hukum pidana, perlu untuk melihat unsur kesengajaan berdasarkan kasus per kasus (animus ad se omne jus ducit) dengan jenis-jenis kesengajaan, yaitu:

1) Kesengajaan sebagai maksud (opzet als oogmerk) adalah keadaan untuk mencapai suatu tujuan.

2) Kesengajaan sebagai kepastian (opzet bij noodzalijkheids of zekerheidsbewustzijn) adalah kesengajaan yang menimbulkan dua

26 Dian Andriawan, wawancara dengan penulis, Dosen Pidana Fakultas Hukum Universitas Tarumanagara, Jakarta, 14 Mei 2018 
akibat. Akibat pertama dikehendaki oleh pelaku, sedang akibat kedua tidak dikehendaki namun pasti atau harus terjadi.

3) Kesengajaan sebagai kemungkinan (opzet bij mogelijkheidsbewustzijn) adakala suatu kesengajaan menimbulkan akibat yang tidak pasti terjadi namun merupakan suatu kemungkinan. ${ }^{27}$

Untuk membuktikan unsur ini harus dibuktikan bahwa unsur pokok dalam pasal yang didakwakan haruslah dilakukan dengan sengaja, dalam hal ini ada kesengajaan dalam menghilangkan nyawa orang lain. Karena dalam kasus putusan ini Terdakwa didakwa dengan pasal tentang membantu suatu kejahatan, sehingga harus dibuktikan bahwa pelaku utama yang mewujudkan delik melakukan kejahatan tersebut dengan sengaja. Dalam hal ini harus dibuktikan bahwa Saksi I dan Saksi II menghilangkan nyawa Korban dengan sengaja.

Bahwa berdasarkan fakta hukum dalam kasus posisi Saksi I dan Saksi II berencana membunuh Korban untuk memperoleh kesaktian, yang dimana perbuatannya itu dilakukan dengan melilitkan akar kayu ke leher korban dan menariknya dengan kuat, bahwa dalam hal ini Saksi I mengharapkan atau menginginkan matinya korban dengan melihat pada unsur kesengajaan sebagai maksud matinya korban. Berdasarkan hal tersebut unsur dengan sengaja tidak terpenuhi menurut hukum pada terdakwa karena kematian korban tidaklah dikehendaki oleh terdakwa terlebih terdakwa tidak mengetahui jika Saksi I dan Saksi II telah melakukan pembunuhan pada korban setelah terdakwa sampai di lokasi tempat terjadinya pembunuhan.

c. Unsur "dengan rencana terlebih dahulu"

${ }^{27}$ Eddy O.S. Hiraej, Op. Cit., hal. 172-174 
Bahwa unsur "direncanakan terlebih dahulu" (moord) adalah antara timbulnya niat dengan pelaksanaan dari niat tersebut terdapat jangka waktu yang memberikan kesempatan bagi pelaku untuk memikirkan secara tenang niat serta akibat yang timbul dari perbuatan yang hendak dilakukannya. ${ }^{28}$ Dalam hal ini harus dibuktikan apakah pelaku sudah memiliki rencana sebelumnya untuk melaksanakan maksud perbuatannya tersebut. Sehubungan dengan hal itu, perlu dilihat rangkaian kejadian atau hal-hal yang terjadi sebelum perbuatan tersebut dilaksanakan, berdasarkan fakta hukum dalam kasus:

1) Berawal dari Saksi II ingin memiliki ilmu kebal dengan harus mencari tumbal yaitu darah 7 (tujuh) orang laki-laki yang nantinya darah tersebut dioleskan ke tubuh. Sebelumnya Saksi II telah membunuh orang sebanyak 7 (tujuh) kali mulai dari tahun 2013, yang mana pembunuhan sebelumnya itu dilakukan bersama dengan Istri Saksi II dan Saksi I.

2) Kemudian pada hari Jumat tanggal 18 Juli 2014 dengan mengendarai sepeda motor Saksi I dan Saksi II pergi ke Kampung Batak untuk mencari anak-laki yang akan diambil darah dan alat kelaminnya. Setelah mendapatkan Korban incarannya, Saksi I kemudian mengajak Terdakwa dan meminjam parang milik Terdakwa di rumah Terdakwa.

3) Korban diajak ke lokasi hutan ekaliptus oleh Saksi II, tempat lokasi yang akan dijadikan sebagai tempat pembunuhan bagi Korban. Setelah korban dihilangkan nyawanya dengan cara dililit lehernya dengan akar kayu, tubuh korban dipotong-potong dan diambil dagingnya dengan menggunakan parang dan pisau cuter

${ }^{28}$ R. Soenarto Soerodibroto, KUHP dan KUHAP Dilengkapi Yurisprudensi Mahkamah Agung dan Hoge Raad, (Jakarta: Rajawali Pres, 2014), hal. 210-211 
serta dagingnya dibungkus dengan kantung plastik, dimana parang, pisau cuter dan plastik sudah dipersiapkan sebelumnya.

4) Bahwa perbuatan Saksi I Saksi II membawa parang, pisau cuter dan kantung plastik sebelum membawa korban ke hutan ekaliptus adalah suatu perbuatan persiapan untuk mewujudkan niatnya. Adanya niat membunuh korban oleh kedua saksi jauh-jauh hari direncanakan. Hal ini karena Saksi II sudah membunuh 6 (enam) orang sebelumnya untuk memiliki ilmu kebal. ${ }^{29}$

Berdasarkan hal-hal tersebut unsur direncanakan lebih dahulu (moord) tidak terpenuhi menurut hukum dikarenakan rencana dilakukan oleh kedua saksi tidak bersama dengan Terdakwa.

d. Unsur "menghilangkan nyawa orang lain"

Unsur ini merupakan tujuan atau maksud dari unsur sebelumnya yakni unsur sengaja artinya menghilangkan nyawa orang lain merupakan maksud dari perbuatan yang dilakukan oleh pelaku perbuatan sehingga perbuatan yang dilakukan pelaku tersebut benarbenar mengakibatkan hilangnya nyawa orang lain.

Untuk membuktikan unsur ini harus ada orang lain yang hilang nyawanya akibat perbuatan yang dilakukan pelaku. Jadi, harus ada hubungan kausalitas atau hubungan sebab akibat dari perbuatan yang dilakukan oleh pelaku dengan matinya korban. ${ }^{30}$

Berdasarkan fakta hukum dalam kasus posisi sebagaimana telah diuraikan dalam penjelasan unsur di atas bahwa korban telah dililit lehernya oleh Saksi I dengan akar kayu sehingga meninggal kemudian bagian tubuhnya dipotong-potong, diambil dagingnya kemudian dijual oleh Saksi I Saksi II. Kematian korban adalah akibat dari perbuatan

${ }^{29}$ Putusan Mahkamah Agung No. 774K / PIID. SUS / 2015

${ }^{30}$ Dian Andriawan, Op. Cit. 
yang dilakukan oleh Saksi I dan Saksi II. Maka unsur ini tidak terpenuhi pada Terdakwa menurut hukum.

\section{Pasal 56 KUHP}

a. Unsur "yang sengaja memberi bantuan pada waktu kejahatan itu dilakukan"

Pasal 56 ke-1 KUHP mengatur tentang pemberian bantuan pada waktu kejahatan dilakukan. Pasal ini merupakan salah satu tindak pidana Penyertaan yang diatur pada Bab V Buku I KUHP dalam Pasal 55 sampai dengan Pasal 62. Dalam mengkualifikasikan siapa saja yang dikatakan sebagai pelaku dan pembantu dinyatakan secara tegas dalam Pasal 55 dan Pasal 56 KUHP. ${ }^{31}$ Oleh kedua pasal tersebut, diadakan lima golongan peserta tindak pidana, yaitu:

1) Mereka yang melakukan perbuatan (pleger);

2) Mereka yang menyuruh melakukan perbuatan (doenpleger);

3) Mereka yang turut melakukan perbuatan (medeplichtige);

4) Mereka yang membantu perbuatan (medeplichtige); dan

5) Mereka yang membujuk supaya perbuatan dilakukan (uitlokker). ${ }^{32}$ Penyertaan dibagi menurut sifatnya:

1) Bentuk penyertaan yang berdiri sendiri (zelfstandige deelneming), adalah tindakan masing-masing peserta dalam melakukan suatu perbuatan pidana diberi penilaian atau kualifikasi tersendiri dan tindakan mereka masing-masing diadili secara sendiri pula.

2) Bentuk penyertaan yang tidak berdiri sendiri (onzelfstanding deelneming), adalah dapat tidaknya seorang peserta dihukum tergantung pada peranannya dalam perbuatan pidana yang telah dilakukan oleh seorang pelaku dan tergantung pula apakah

${ }^{31}$ Eddy O.S. Hiraej, Op. Cit., hal. 349

${ }^{32}$ Ibid., hal. 351 
perbuatan yang dilakukan oleh pelakunya itu merupakan suatu tindak pidana atau bukan. ${ }^{33}$

Penyertaan (deelneming) mempersoalkan peranan atau hubungan tiap-tiap peserta dalam suatu pelaksanaan tindak pidana, sumbangan apa yang diberikan oleh tiap-tiap peserta, agar tindak pidana itu dapat dilaksanakan / diselesaikan, serta pertanggungjawaban atas sumbangan / bantuan itu. Orang yang dapat dituntut menurut pasal ini adalah orang yang sengaja membantu melakukan kejahatan pada waktu sebelum atau ketika kejahatan tersebut sedang dilaksanakan.

Dalam kasus terdapat bahwa Terdakwa mendapat suatu ancaman dimana mendengar perkataan Saksi I yang mengatakan, "Kamu mau seperti ini" sehingga Terdakwa mau membantu membuka dan mengikat plastik yang berisi daging Korban atas permintaan Saksi II. Akan tetapi setelah tiba di rumah, Terdakwa tidak melakukan perbuatan apapun yang seharusnya dilakukan. Terdakwa seharusnya melaporkan kejadian tersebut kepada pihak yang berwajib atau kepada orang tua Terdakwa karena Terdakwa telah melihat atau mengetahui adanya suatu kejahatan atau tindak pidana. Padahal dalam hal ini Terdakwa sudah dalam keadaan bebas, dan ancaman terhadap Terdakwa sudah tidak ada lagi. Dalam hal ini Terdakwa tidak melakukan perbuatan yang seharusnya dilakukan.

\section{Pasal 1 ke-3 UU SPPA}

a. Unsur "Anak"

Menurut UU SPPA dalam Pasal 1 ke-3 yang dimaksud dengan anak yang berkonflik dengan hukum selanjutnya disebut dengan anak adalah anak yang telah berumur 12 (dua belas) tahun, tetapi belum berumur 18 (delapan belas) tahun yang diduga melakukan tindak

${ }^{33}$ Ibid. 
pidana. ${ }^{34}$ Berdasarkan fakta hukum dalam kasus posisi dan di persidangan, dan identitas lain (Kartu Keluarga), bahwa Terdakwa lahir pada tanggal 04 Agustus 1997. Dengan demikian Terdakwa pada saat itu belum berumur 18 (delapan belas) tahun dan karenanya termasuk dalam kategori anak menurut UU SPPA.

Oleh karena semua unsur dari Pasal 340 KUHP, Pasal 56 ke-1 KUHP, dan Pasal 1 ke-3 UU SPPA hanya terpenuhi sebagian unsur dari pasal yang didakwakan, yaitu hanya pada Pasal 1 ke-3 UU SPPA, maka Terdakwa dinyatakan tidak terbukti melakukan tindak pidana sebagaimana didakwakan oleh Jaksa Penuntut Umum dan juga pada putusan Pengadilan Negeri yang memeriksa kasus terdakwa Dicky Pranata tersebut.

\section{Pasal 181 KUHP}

a. Unsur "Barangsiapa"

Barang siapa adalah setiap orang atau siapa saja selaku subyek hukum, pendukung hak serta kewajiban, serta dapat dikenakan pertanggungjawaban pidana. ${ }^{35}$ Berdasarkan fakta hukum, bahwa Terdakwa Dicky Pranata adalah seorang anak berusia 16 (enam belas) tahun. Sebagaimana tercantum mengenai identitas Terdakwa di dalam dakwaan dan putusan pengadilan sehingga dalam hal ini tidak terjadi error in persona.

b. Unsur "mengubur, menyembunyikan, membawa lari, atau menghilangkan mayat"

1) Unsur mengubur dalam pembahasan pasal ini ialah menimbun mayat dengan daun-daun kering.

2) Unsur menyembunyikan dalam pembahasan pasal ini ialah menyembunyikan mayat korban dengan menimbuni

${ }^{34}$ UU SPPA, Op. Cit., Pasal 1 angka 3

${ }^{35}$ Dian Andriawan, Op. Cit. 
menggunakan daun-daun kering di suatu tempat agar tidak diketahui oleh orang lain.

3) Unsur membawa dalam pembahasan pasal ini ialah mengangkut daging korban yang sudah dipotong-potong dimasukkan dalam 7 (tujuh) kantong plastik dibawa dengan menggunakan kendaraan yaitu sebuah sepeda motor dilakukan terdakwa bersama kedua saksi pelaku tindak pidana pembunuhan.

4) Unsur menghilangkan mayat dalam pembahasan pasal ini ialah bahwa terdakwa mengetahui jika akan menjual daging korban ke warung makan.

c. Unsur "dengan maksud hendak menyembunyikan kematiannya"

Dalam unsur ini Terdakwa lakukan agar tidak diketahui oleh orang lain, yang mana Terdakwa tidak pernah melaporkan kejadian pembunuhan pada Korban kepada pihak berwenang atau pun kepada orang tua Terdakwa sendiri.

5. Pasal 56 KUHP

a. Unsur "yang sengaja memberi bantuan pada waktu kejahatan itu dilakukan"

Berdasarkan penjelasan unsur-unsur sebelumnya Pasal 181 KUHP bahwa Saksi I, Saksi II, dan Terdakwa terbukti melakukan pemindahan dan penghilangan mayat Korban. Berdasarkan fakta hukum dalam kasus kejadian bahwa Terdakwa ikut mengikat plastik yang berisi daging korban dan ikut menggesernya dengan memindahkan sebagian tubuh korban (7 (tujuh) kantong plastik berisi daging, jantung, dan alat kelamin), yang mana pemindahan dilakukan menggunakan kendaraan bermotor dengan berbonceng tiga.

Selanjutnya membahas permasalahan kedua mengenai dasar peringanan pidana dalam kasus Putusan Mahkamah Agung No. 774K / PID.SUS / 2015 adalah melihat pada Pasal 56 ayat (1) ke-1 KUHP bahwa terdakwa telah 
melakukan pembantuan pada kedua pelaku tindak pidana pembunuhan berencana, yaitu dengan membantu kedua pelaku dalam menyembunyikan, memindahkan, dan menghilangkan mayat korban seperti yang ada pada unsur dalam Pasal 181 KUHP.

Berdasarkan fakta-fakta yuridis yang terungkap dalam persidangan tersebut maka dakwaan terhadap Terdakwa tidaklah terbukti secara sah dan meyakinkan. Tetapi penulis menemukan adanya tindak pidana lain yang dilakukan oleh Terdakwa terhadap mayat Korban. Hal tersebut mungkin saja dapat terjadi, karena hakim dalam memutuskan suatu perkara hanya berdasarkan surat dakwaan yang diberikan oleh Penuntut Umum. Dalam kasus ini Penuntut Umum memberikan surat dakwaan subsidair, sedangkan pada kasus ini dakwaan dapat dibuat menjadi kumulatif yaitu mengenai Pasal 340 KUHP dan Pasal 181 KUHP. Sehingga Terdakwa tidaklah lepas dari tuntutan pidana, dimana perbuatan Terdakwa disini banyak mendapatkan kontraversi dari banyak masyarakat terhadap bebasnya Terdakwa dari pidana.

Sesuai dengan perkembangan ilmu pengetahuan hukum pidana, bahwa pidana tidaklah lagi semata-mata sebagai pembalasan bagi terpidana atas perbuatan kejahatan yang dilakukannya, melainkan berfungsi juga sebagai memperbaiki terpidana sendiri, agar sekembalinya terpidana ke dalam ruang lingkup masyarakat umum, dirinya dapat diterima kembali di masyarakat dengan baik. Selain itu juga, penjatuhan pidana pada seorang yang melakukan kejahatan, dapat membantu pengadilan memperoleh kepercayaan masyarakat dalam menegakkan keadilan. Terlebih sekarang ini semakin banyaknya masyarakat luas kurang puas akan kinerja pengadilan dalam memberikan putusan pada para petindak kejahatan pidana yang dianggap kurang adil dalam menjatuhkan hukuman. Karenanya, tepatlah kiranya, apabila Terdakwa pada kasus ini dijatuhi dengan hukuman yang setimpal dengan perbuatannya.

\section{III.PENUTUP}




\section{A. Kesimpulan}

Berdasarkan hasil analisis dan pembahasan, maka ditarik kesimpulan sebagai berikut:

1. Pertimbangan dan dasar hukum hakim Mahkamah Agung dalam menjatuhkan putusan No. 774K / PID.SUS / 2015 sudahlah tepat dengan menelaah kronologis kejadian dimana Terdakwa tidak sama sekali mengetahui rencana dari perbuatan pembunuhan berencana kepada Korban. Putusan ini mempertegas dari putusan Pengadilan Tinggi yang membatalkan putusan Pengadilan Negeri tingkat pertama, dengan memutus bebas terdakwa karena tidak terbukti melakukan perbuatan yang didakwakan dalam pembantuan pembunuhan berencana.

2. Putusan Mahkamah Agung ini setelah menilai putusan Pengadilan Tingi yang tidak bertentangan dengan hukum dan ditambah dengan perbuatan terdakwa membantu ini, karena berada dibawah ancaman para pembunuh korban. Sehingga perbuatan terdakwa ini bukan termasuk unsur pembantuan karena berada dibawah ancaman dalam melakukan pembantuan dan unsur kesengajaan tidak terbukti. Sebab Pasal 56 ayat (1) harus ada unsur sengaja membantu kejahatan dan ini tidak terbukti.

\section{B. Saran}

Setelah mengetahui kronologis peristiwa yang diungkapkan dari keterangan Terdakwa maupun kedua saksi dalam kasus putusan maka diharapkan para aparat penegak pengadilan dikhususkan pada Jaksa Penuntut Umum dalam menuntut pasal pada seorang pelaku tindak pidana untuk lebih berhati-hati dalam menjalankan tugasnya. Dalam penelitian ini dakwaan Jaksa diharapkan menyertakan juga Pasal 181 KUHP, dengan menyertakan Pasal 181 KUHP dalam surat dakwaannya, maka dakwaan Jaksa menjadi dakwaan Kumulatif dengan dakwaan pertama yaitu Pasal 340 juncto Pasal 56 ke-1 KUHP juncto Pasal 1 ke-3 UU SPPA dan dakwaan kedua Pasal 181 juncto Pasal 56 ke-1 KUHP juncto Pasal 1 ke-3 UU SPPA, dengan menguraikan 
kembali fakta-fakta kejadian yang ada dengan unsur yang ada dalam pasal. Hal ini dilakukan untuk menghindari Terdakwa dari putusan bebas. Karena jika Terdakwa terbebas dari dakwaan Pasal 340 KUHP, maka Hakim dapat mempertimbangkan dengan melihat pada Pasal 181 KUHP. Melihat dari perbuatan Terdakwa yang ikut serta dalam menghilangkan, memindahkan, dan menyembunyikan mayat kematian Korban, dengan ancaman pidana 9 (sembilan) bulan pidana dengan pertimbangan bahwa Terdakwa adalah seorang anak yang akan mendapat pengurangan kurungan pidana $1 / 2$ dari kurungan pidana orang dewasa, menjadi 4 (empat) bulan penjara dikurangi dengan masa selama Terdakwa ditahan.

\section{DAFTAR PUSTAKA}

A. Buku

Anwar, H.A.K. Moch. Beberapa Ketentuan Umum dalam Buku Pertama KUHP. (Bandung: Alumni, 1986)

Asnawi, Natsir M. Hermeneutika Putusan Hakim. (Yogyakarta: UII Press Yogyakarta, 2014)

Fuady, Munir. Teori Negara Hukum Modern (Rechstaat). (Bandung: PT Refika Aditama, 2009)

Hidayat, Bunadi. Pemidanaan Anak di Bawah Umur. (Bandung: PT Alumni, 2010)

Hiraej, Eddy O.S. Prinsip-Prinsip Hukum Pidana, Edisi Revisi. (Yogyakarta: Cahaya Atma Pustaka, 2015)

Lamintang, P.A.F dan Franciscus Theojunior Lamintang. Dasar-Dasar Hukum Pidana di Indonesia, Cetakan ke-2, (Jakarta: Sinar Grafika, 2016)

Muladi dan Barda Nawawi. Teori-Teori dan Kebijakan Pidana. (Bandung: Alumni, 1992)

Pawennei, Mulyati dan Rahmanuddin Tomalili. Hukum Pidana. (Jakarta: Mitra Wacana Media, 2015)

Prodjodikoro, Wirjono. Asas-Asas Hukum Pidana di Indonesia. (Bandung: PT Refika Aditama, 2014)

Rusianto, Agus. Tindak Pidana dan Pertanggungjawaban Pidana; Tinjauan Kritis Melalui Konsistensi antara Asas, Teori, dan Penerapannya. (Jakarta: Pranamedia Group, 2016)

Saleh, Roeslan. Sifat Melawan Hukum dari Perbuatan Pidana. (Jakarta: Aksara Baru, 1983) 
Sutiyoso, Bambang. Metode Penemuan Hukum. Cetakan ke-4. (Yogyakarta: UII Press, 2012)

Soesilo, R. Kitab Undang-Undang Hukum Pidana (KUHP) Serta KomentarKomentarnya Lengkap Pasal Demi Pasal. (Bogor: Politeia, 1976)

Soerodibroto, R. Soenarto. KUHP dan KUHAP Dilengkapi Yurisprudensi

Mahkamah Agung dan Hoge Raad. (Jakarta: Rajawali Pres, 2014)

B. Peraturan Perundang-undangan

Indonesia. Undang-Undang Dasar Negara Republik Indonesia Tahun 1945. . Kitab Undang-Undang Hukum Pidana. . Undang-Undang Nomor 17 Tahun 2016 tentang Perubahan Kedua Atas Undang-Undang Nomor 23 Tahun 2002 Tentang Perlindungan Anak . Undang-Undang Nomor 11 Tahun 2012 tentang Sistem Peradilan Pidana Anak.

C. Putusan Pengadilan

Indonesia. Putusan Pengadilan Negeri No.05 /PID.SUS.ANAK/2014 /PN.Siak /PT.PBR - Putusan Pengadilan Tinggi No. 01 /PID.SUS /ANAK /2014

D. Wawancara

Putusan Mahkamah Agung No. 774K/PID.SUS / 2015

Wijaya, Firman. Wawancara dengan penulis, Fakultas Hukum Universitas Tarumanagara. Jakarta, 8 Mei 2018.

Andriawan, Dian. Wawancara dengan Penulis, Fakultas Hukum Universitas Trisakti. Jakarta, 14 Mei 2018. 